\section{ノ- r}

〔農化 第 52 巻，第 10 号，p. 489 491，1978]

温州ミカン (Citrus unshiu Marc.)

果実に拈けるエチレンによるクロロ

フィラーゼの活性化について

嶋田誠一*，下川敬之**

（* 金子農機株式会社技術センター，

** 宮崎大学烪学部)

昭和 53 年 5 月 1 日受理

Ethylene-activated Chlorophyllase in Satsuma

Mandarin (Citrus unshiu Marc.) Fruits

Seiichi SHIMAdA* and Keishi SHIMOKaWA**

* Kaneko Agric. Machinery Co. Ltd., Hanyu, Saitama and ** Faculty of Agriculture,

Miyazaki University, Miyazaki 880

Effects of ethylene on chlorophyllase activity and chlorophyll degradation in peels of Satsuma mandarin (Citrus unshiu Marc.) fruits were studied using an ethylene-flow system to prevent the inhibitory effect of $\mathrm{CO}_{2}$ on the ethylene action. Chlorophyllase activity and chlorophyll degradation were not increased by exposing to ethylene. After exposing the ethylene-treated fruits to air, chlorophyllase activity and chlorophyll degradation were acceralated simultaneously.

Based on these results, a role of ethylene in chlorophyll degradation of the fruits is discussed briefly.

(Received May 1, 1978)

エチレンのクロ フィル分解促進作用は広く知られて 扣り，方が国では，西南暖地特有の果肉先熟現象を是す る温州ミカン果実の貺緑（クロロフィル分解）促進のた め，このエチレンの性質を利用して，商品価値を高める 方法がしだい普及してきだ(1,2)。

著者らは，エチレンによる脱緑をより效果的に行なら ためにはまずエチレンによる脱緑機構を明らかにする 必要があると考え，エテレンとクロロフィル分解活性の 関係索明らがするため，温州ミカン累皮のクロロフ、 几分解醉素に着目し，その諸性質，エチレンによる活性 の変化，活性に対する蛋白質合成阻害剂の影響などにつ
いて研究をすすめてきた。その結果，エチレン好理によ る温州ミカン果皮のクロロフィル分解促進に，ある種の クロロフィル分解酵素が関与し，エチレンがこの醉素の 活性を增加させること、この酵素がクロロフィラーゼ (EC 3.1.1.14) である可能性が高いこと，さらに，エチ

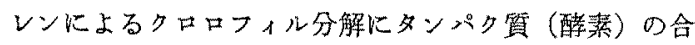

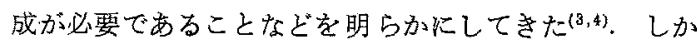
し，これらの研究はエチレン処理孛 12 時間密封状熊 (以下，クローズド・システムとする)で行なったるの であり，エチレン処理終了時の 12 時間目には，温州ミ カン果実による呼吸のため装置内の $\mathrm{CO}_{2}$ 濃度は 10 \%にも達していた(5)， $\mathrm{CO}_{2}$ はエチンンの生理作用に対 寸る拮抗的阻害剂であり(8)，先の結果 ${ }^{(3,4)}$ は $\mathrm{CO}_{2}$ の影響 を受けていて，真のェチレン效果を見ていない可能性が ある、そこで，本研究では， $\mathrm{CO}_{2}$ の蓄積の少ない装置で のエチレン処理による, 温州ミカン果皮のクロロフィル 含量およびクロロフィラーゼ活性の变化を明らかにする ために，通気状熊 (以下，フトー・システムとする）で 温州ミカン果金のエチレン処理を行なった。

温州ミカン果実は, 1977 年 10 月〜11 月にかけて, 宮 崎県宮崎郡清武町の石川忠行氏のミカン園より，実験前 日に採取した 〜〜2分着色の果実を使用した。

Fig.1 に示すフロー・システムで，エチレンガス $\left(\mathrm{C}_{2} \mathrm{H}_{4} 52 \mathrm{ppm} /\right.$ 人工空気中）を流速 $100 \mathrm{ml} /$ 分で 12 時 間通気乙て行なった。この際，エチレンを会案ない人工 空気を同じ流速で同じ時間だけ通気したものを対照区之 した. 12 時間の通気終了啳は対照区，処理区共以驾氛 中においた.なお，エチレン処理区，対照区共に処理は

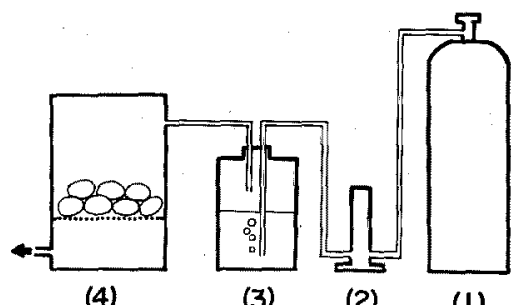

Fig. 1. Apparatus for Gas-fiow Treatment. (1) gas cylinder, control: authentic gas mixture $\left(\mathrm{N}_{2} 80 \%: \mathrm{O}_{2} 20 \%\right)$, ethylene treatment : gas mixture containing $52 \mathrm{ppm}$ of ethylene in the authentic gas mixture. (2) gas flow meter. (3) gas reservoir containing water (apparatus for adding humidity to gas mixtures). container of fruits. 


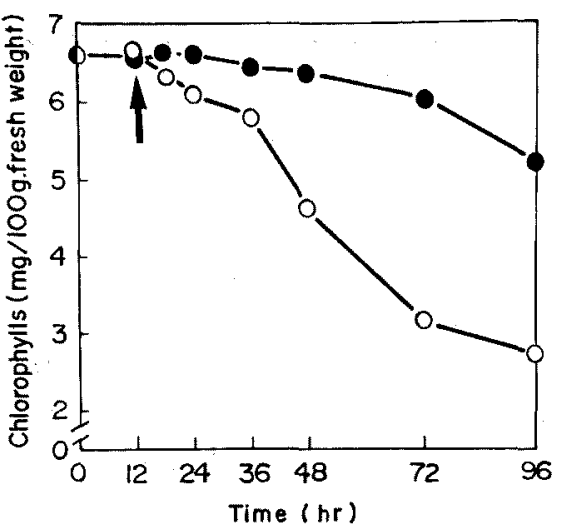

Fig. 2. Ethylene-activated Chlorophyll Degradation in the Peel of Satsuma Mandarin Fruits. -, control fruits; 0 , ethylene-treated fruits. The arrow indicates the end of ethylene treatment.

$20^{\circ} \mathrm{C}$ の定温室内で腤黒下に行なった。

果皮のクロロフィル定量, 基質としてのクロロフィル 溶液の調製，クロロフィラーゼ活性の測定，蛋白質の定 量法などはすべて前報(3)で述べた方法によって行なっ た。また，本研究で用いたりロロフィラーゼ標品はアセ トン粉末からトリトン X-100 で可溶化した画分であり， その調製法は前報 ${ }^{(3)}$ に述べた。

対照区のクロロフィル含量は，通気時間も含めて 48 時間目まで変化せず，その啳，わずか減少し，96 時 間目の含量はゼロタイムの $80 \%$ となったここれに対し， エチレン処理区では，エチレン処理終了時の 12 時間目， つまり，空気中に和したときから36 時間目にかけて余 徐に隇少し，その後，さらにこの減少傾向は続き，96 時間目での含量はゼロタイムの $50 \%$ となった(Fig.2). 一万, クロロフィラーゼ活性は対照区では通気中の 12 時間を含めて 96 時間目まで增加しないのに対し，エチ レン処理区では，エチレンガス通気中の 12 時間には活 性の増加は認められず, 通気終了後, 空気中に秋すとし だいに活性は增加しこの傾向は60時間目まで続いた。 しかし，その後，96 時間目までは減少した（Fig.3).

温州ミカン果実を，クローズド・システムで 12 時間 エチレン妈理すると, システム内の $\mathrm{CO}_{2}$ 浀度は開封直 前には $10 \%$ に達する(5). この場合,クロロフィルの分 解量とクロロフィラーゼ活性の增加は，12 時間のエチ レン処理後開封して 6 時間目，つまりエテレン処理開始 後 18 時間目に始まっだ(4)。れに対し，今回のフゅ

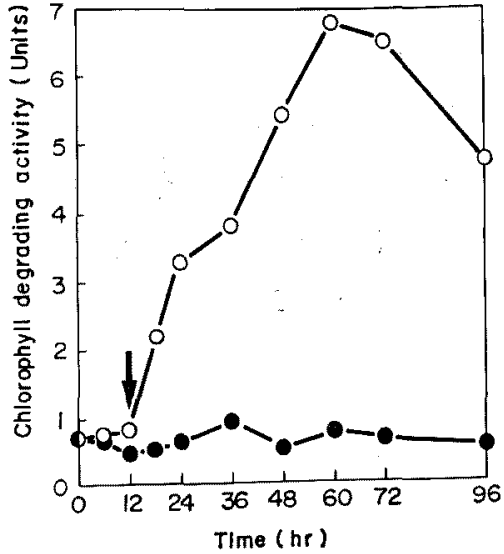

Fig. 3. Ethylene-activated Chlorophyllase in the Peel of Satsuma Mandarin Fruits. •, control fruits.; $O$, ethylene-treated fruits. For arrow; see Fig. 2.

一・システムではェチレン処理中の装置内の $\mathrm{CO}_{2}$ 濃度 は $0.25 \%$ と低濃度に保たれ，ク口甘フィルの分解量上 分解活性の增加開始はクトーズド・システムの場合より も6 時間だけ短縮され，エチレン処理啳，空気中に移す と始まった。つまり，クローズド・システムであろう が，フロー・システムであるらが，エチレンガス処理中 にはクロロフィルの分解と分解活性の增加は諗められな かった。

この6時間の違いの原因としては次のようなことが考 えられる.クローズド・システムでは 12 時間のエチレ ン処理期間中にシステム内に $\mathrm{CO}_{2}$ が高濃度に蓄積し,

Burg ら(6)により明らかにされているよらなェチレンの 生理作用に対する $\mathrm{CO}_{2}$ による阻害效果が現われ，エチ レンによるクロロフィル分解が抑制されたと考劣ること もできる。しかし，高濃度の $\mathrm{CO}_{2}$ 自身によるクロロフ イル分解開始の阻害メカニズムの存在の可能性むあり， この点についてはさらに検討しなければならない，

また， $\mathrm{CO}_{2}$ ととるに $\mathrm{O}_{2}$ 濃度の影響も考劣られる。本 研究では $\mathrm{O}_{2}$ 濃度を測定しなかったが，北川らの報告で は, 密封法によるエチレン処理で 12 時間後の $\mathrm{O}_{2}$ 濃度 は低下しているが，10\% 程度は残って未り(7)，クロー ズド・システムとフロー・システムでのエテレン処理果 実のクロロフィル分解量と分解活性の增加に要する時間 の美に，酸素湄度はあまり影響しないのであろら．しか し，一般に果実の成熟には酸素か必要とされて和り，酸 素濃度の影響については，今後の検討が必要であるら。 
第 10 号, 10 月了 温州ミカン果奏に拈けるェチレンによるクロロフィラーセの活性化について

北川ら (1)や下川ら(2)のクローズト・システムでのエチ レン処理法によると，72〜96 库間目までにェチレン処 理果と槃処理果のクロロフィル含量に明確な差が出るこ とが知られている、束た、前報のクローズド・システム と本報のフロー・システムの雨システえ間で, クロロフ 1 认分解の開始時期に6時間の差はあるが，72〜96 時 間目での両システムでのクロロフィル含量の最終的な䔔 いは少ないことから，北川ら ${ }^{(8)}$ が指摘するように、トリ クル法やショット法のような $\mathrm{CO}_{2}$ の䈏積を防ぐための

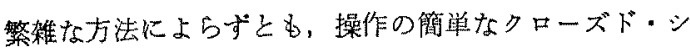
ステムでのエチレン処理で実用的には充分な效果が期街 でさる。

Barmore ${ }^{(9)}$ は土チレン処理によってカラマンディン果 皮のクロロフィル分解活性が増加し，クロロフィル分解 が促進され，この活性增加に細胞質䤃素の合成が関与す ることを報告し，著者占も温州ミカン泪皮で同様の結果 を得た(4). また下川と共同研究者は，エチレン処理によ って誘導される温州ミカン果皮のクロロブラストの形態 的老化の現象として，エチレン処理後 36 時間目以は， クロロプラストは消失または小型化することを钼察して いる(10).さらら温州ミカン果実のクロロフィル分解過 程飞おけるクロロプラスト自体あるいはラメラ棈造の変 化を電子顕锁鏡により観察して，エチレンによる特異的 な構造変化の存在を明らかにしている(11). クロロフィ

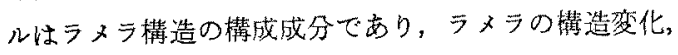
その結果としてのクロロプラストの形態的老化とクロ口 フィルの分解機構とは密接な関保があるはずであり，今 媵，追及していかねばならない課題の一つである。

エキレン処理果契のクロロフィル分解妨クロロフィラ
一ゼ活性の㙕加を伴5のに対し，無処理果实では 72 特 間目からクロロフィル分解が始まるが，クサロフィラー

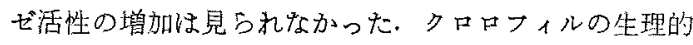
な分解の機作についての究明惟んでいないが，ク口 ロフィラーゼによる分解以外にいくつかの分解样式が断

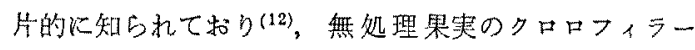
ゼ活性增加を伴わないクロロフィルの分解は、アせトン 粉末からトリトンX-100で抽出されるクトロフィル分 解酵素とは別のものによって行なかれている可能性があ る.エチレンによる眖緑性暗黑下で進行しており、ェキ レンによるクロロフィル分解促進には，光淔接関与し ていないるの上思われる。

（1）北什博敏，足立修三，榑谷隆之: 圆蔭学会維 諘，40，195 (1973).

（2）下川敬之：農業执よび園芸，51，987（1976）.

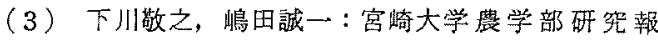
靠, 24, 309 (1977).

(4) K. Shimokawa, S. Shimada and K. Yaeo: Scientia Hort., 8, 129 (1978).

（5）下山敬之：温州ミカンの羙色促進问関する研 究, 1972 .

(6) S.P. Burg and E. A. Burg: Science, 148, 1190 (1965).

（7）北川博敏, 榑谷隆之：園芸学会雑誌，42, 65 (1973).

(8) 北㸪博敏: “ミカンのカラリング”, 誠文堂新光 社, 1974 .

(9) C. R. Barmore : Hortscience, 10, 595(1975).

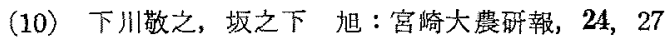
(1976).

(11) K. Shimokawa, A. Sakanoshita and K. Horiba: Plant Cell Physiol., 19, 229(1978).

（12）清水 硕：生物科学, 23, 31 (1971). 